\title{
Purification of Functional HEV-ORF2 Protein from Inclusion Bodies for Vaccine and Diagnostic Applications
}

\author{
Fatemeh Motevalli $^{1}$ (D) , Mohammad Reza Amiran ${ }^{\text {q11 }}$ (D), Mazyar Etemadzadeh ${ }^{1}$, Golnaz Bahramali ${ }^{1,5}$ (D), Soroush Sardari ${ }^{2}$ \\ , Seyede Zahra Moravej ${ }^{1}$, Pooneh Rahimi ${ }^{1,5}$ (D) , Abolfazl Fateh ${ }^{3}$ (D), Seyed Alireza Seyed Siamdoust ${ }^{4}$ (D), Mohammad Ali \\ Zaheri Birgani $^{1}$, Mojtaba Hamidi-Fard ${ }^{* 1,5}$ (D) \\ ${ }^{1}$ Department of Hepatitis and AIDS, Pasteur Institute of Iran, Tehran, Iran; ${ }^{2}$ Drug Design and Bioinformatics Unit, Medical \\ Biotechnology Department, Biotechnology Research Center, Pasteur Institute of Iran, Tehran, Iran; ${ }^{3}$ Department of \\ Mycobacteriology and Pulmonary Research, Pasteur Institute of Iran, Tehran, Iran; ${ }^{4}$ Iran University of Medical Sciences, Tehran, \\ Iran; ${ }^{5}$ Viral Vaccine Research Center, Pasteur Institute of Iran, Tehran, Iran
}

\begin{tabular}{|c|c|}
\hline A R T ICLE IN F O & A B S T R A C T \\
\hline Original Article & $\begin{array}{l}\text { atroduction: Hepatitis } \mathrm{E} \text { virus (HEV) causes emerging diseases in poor regions of the } \\
\text { orld. The ORF2 is the only protein encoded by the virus to make the viral capsid. The }\end{array}$ \\
\hline VacRes, 2020 & $\mathrm{~g}$ ORF2 is a major \\
\hline o. $1,44-49$ & eering. Methods: The ORF2 conserved sequence was expressed it \\
\hline Received: June 09, 2020 & L21 and assessed by a modified SDS-PAGE containing a wea \\
\hline Accepted: August 16, 2020 & the recombinant $\mathrm{ORH}$ \\
\hline Pasteur Institute of Iran & The protein of inte \\
\hline *Corresponding Auth & homology modeling by I-TA \\
\hline Hamidi-Fard; Viral Va & $e d$ \\
\hline $\begin{array}{l}\text { Center, Pasteur Institute of Iran, } \\
\text { Tehran, Iran, 12th Farvardin, Enghelab }\end{array}$ & expressed in E. coli BL21 and was confirmed by SDS-PAGE and Western blottin \\
\hline square, Tehran, Iran. & \\
\hline Email: mojtaba_hamidifard@yahoo.com & interest demonstrated that the native st \\
\hline Tel/Fax: (+ 98)21669692 & \\
\hline $\begin{array}{l}\text { IICo-First Author: Mohammad Reza } \\
\text { Amiran }\end{array}$ & entrations of urea and detergents to overcome the aggregation of ORF2 protein in IE \\
\hline $\begin{array}{l}\text { KEYWORDS: Hepatitis E virus, } \\
\text { ORF2, Inclusion bodies, Protein } \\
\text { solubilization }\end{array}$ & $\begin{array}{l}\text { Citation: } \\
\text { Motevalli F, Amiran M R, Etemadzadeh M, Bahramali G, Sardari S, Moravej S Z, et al . Purification of Functional } \\
\text { HEV-ORF2 Protein from Inclusion Bodies for Vaccine and Diagnostic Applications. vacres. 2020; } 7 \text { (1) :44-49. DOI: } \\
\text { 10.29252/vacres.7.1.44 }\end{array}$ \\
\hline
\end{tabular}

\section{INTRODUCTION}

Hepatitis E virus (HEV) causes an emerging disease in poor regions of the globe. Approximately one-third of people living in developing countries have been infected with HEV [1, 2]. The HEV is a non-enveloped virus containing a positivesense, single-stranded RNA genome of $\sim 7.2 \mathrm{kbp}$ that encodes ORF1 nonstructural polyprotein which is responsible for biochemical functions, ORF2 major viral capsid protein that causes virus interactions with the target cells, and ORF3 which encodes a 660-amino-acid viral capsid protein [3, 4]. The ORF2 is the only single protein to make the viral capsids and it provokes the immune system to release neutralizing antibodies[5] Therefore, it has been studied to achieve efficient antigens for both diagnostic and vaccine development purposes, as follows.

Different heterologous systems to express various recombinant forms of ORF2 protein are being developed [6]. HEV capsid proteins have been expressed in a vast range of systems such as Escherichia coli, plants, yeast, insect cells, and mammalian cells; amongst them, p495 and P239, have been used for clinical trials. The p239 (aa 368-606) has been expressed in E. coli via in vitro VLP assembly. The p239 was licensed as a vaccine and launched by Chinese scientists at the end of 2012 (trade name: Hecolin) that protected healthy adults against HEV infection for up to 4.5 years [7]. Hecolin (HEV 239 vaccine) is the only available HEV vaccine in China.

In our previous study, we used Sf9 cells to express ORF2, and the result showed that the protein of interest was expressed successfully [8]. Before this study, we applied different concentrations of IPTG on E. coli BL21 containing pET26bORF2 to evaluate the expression of the truncated ORF2 protein in which no significant difference was observed [9]. E. coli is a common expression system for therapeutic protein production due to its low cost and simplicity [10]. Proteins aggregation as inclusion bodies (IBs) is a common problem in bioengineering. Although the expression as IBs can be beneficial for the yield, the separation procedure is often time-consuming and 
experimental [11]. The protein solubility correlates with its correct folding; therefore, the isolation process should not cause damage to the protein structure and its quality $[12,13]$. Thus, before the purification step of the expressed protein by chromatography, the aggregated ORF2 requires solubilization processes. The pre-purification steps significantly affect the overall protein recovery [14]. There are some factors that can minimize the formation of IBs such as alteration of the temperature, the induction time, the inducer concentration, the media composition as well as the plasmid-related properties such as the promoter strength, the plasmid copy number and the host strain. Nevertheless, these factors still need to be optimized for some proteins to get soluble products [13, 15]. People infected with $\mathrm{HEV}$, release $\operatorname{IgG}$ and $\operatorname{IgM}$ in their blood before the manifestation of the clinical symptoms; therefore, the disease can be detected by ELISA plates, coated with ORF2 protein of HEV[16].

In the present study, we attempted to obtain ORF2-HEV in its native structure. The purified proteins were characterized using circular dichroism (CD). To assess whether these methods could possibly be applied for the recombinant HEV vaccine production, the recombinant protein's function was also evaluated by ELISA, using sera of HEV patients.

\section{MATERIALS and METHODS}

\section{Ethics Statement}

Inform consents were provided by HEV patients for using their sera in this study performed according to the rules of the Ethical Committee of Pasteur Institute of Iran.

\section{ORF2 Sequence Preparation}

The sequence of ORF2 (GenBank Accession No M80581.1; protein id AAA45727.1) and the precursor amino acid sequences were obtained from NCBI databank. The ORF2 was excised from pUC57-ORF2 with NdeI/NotI restriction enzymes and subcloned into the same restriction sites in pET26b added by a C-terminal His-tag to the coding sequence. Following sub-cloning and confirming the procedure, PCR, restriction enzyme digestion, and DNA sequencing were performed. The PCR was conducted using T7 promoter primer \#69348-3 (5'-TAATACGACTCACTATAGGG-3') and T7 terminator primer \#69337-3 (5'-GCTAGTTATTGCTCAGCGG $\left.-3^{\prime}\right)$.

\section{SDS-PAGE and Western Blotting}

pET26b-ORF2 was transformed into E. coli BL21 (DE3), and a single colony was cultured at $37^{\circ} \mathrm{C}$ in TY2X. At $\mathrm{OD}=0.5$ (600nm), the culture was induced with $0.5 \mathrm{mM}$ IPTG. To optimize the expression conditions, the expressions at 2, 3 and $5 \mathrm{~h}$ after the induction were monitored, and samples were collected following $0,2,3$ and $5 \mathrm{~h}$ post-induction. The expressions were evaluated over $12 \%$ SDS-PAGE. The proteins were then blotted to a nitrocellulose membrane, and the recombinant His-tagged ORF2 was detected using anti-His-Tag $\mathrm{mAb}$ (Sigma-Aldrich, Germany) as the primary antibody at $4^{\circ} \mathrm{C}$ overnight and HRP-conjugated IgG antibody (Sigma-Aldrich, Germany) for $1 \mathrm{~h}$ at room temperature. The bands were revealed by DAB (Roche, Switzerland).

\section{Solubility Assay}

The amount of $0.5 \mathrm{ml}$ aliquot of an overnight culture of E. coli BL21 containing pET23b was seeded into a $50 \mathrm{ml}$ of fresh TY2X medium supplemented with $50 \mu \mathrm{g} / \mathrm{ml}$ ampicillin and grown to the OD 600 of about $0.5 \mathrm{ppm}$ at $37^{\circ} \mathrm{C}$. One $\mathrm{mM}$ IPTG was used to induce protein expression. The cells were cultured at $37^{\circ} \mathrm{C}$ for $3 \mathrm{~h}$ and centrifuged at $6,000 \times \mathrm{g}$ for $20 \mathrm{~min}$, then harvested. The cell pellets were suspended in PBS and incubated on ice for $30 \mathrm{~min}$, followed by sonication at $200 \mathrm{~W}$ (10 times for $10 \mathrm{sec} / \mathrm{each}$ ) using a UP200Ht Hielscher sonicator (Hielscher Ultrasonics $\mathrm{GmbH}$, Germany) and harvested the bacterial pellet at $10,000 \mathrm{x}$ g for $20 \mathrm{~min}$. The soluble fraction (supernatant) was assessed by using SDS-PAGE and Coomassie blue staining, and an insoluble fraction (pellet) was resuspended in lysis buffer before the process was repeated twice and analyzed.

\section{Solubilization of Recombinant ORF2 Under Various Conditions of Temperature and Inducer Concentration}

The E. coli BL21 was cultured in $250 \mathrm{ml}$ of medium and recombinant $\mathrm{ORF} 2$ was expressed at $18^{\circ} \mathrm{C}$ for $20 \mathrm{~h}, 28^{\circ} \mathrm{C}$ for 5 $\mathrm{h}, 37^{\circ} \mathrm{C}$ for $3 \mathrm{~h}$ and optimized by adding various concentrations $(0.1,0.5$ and $1 \mathrm{mM})$ of IPTG. The harvested cells were suspended into $25 \mathrm{ml}$ of lysis buffer $(50 \mathrm{mM}$ Tris- $\mathrm{HCl},(\mathrm{pH} 8)$, $0.5 \mathrm{mM}$ EDTA, $0.1 \%$ Triton $\mathrm{X}-100,0.1 \%$ Tween $-20,1 \mathrm{mg} / \mathrm{ml}$ lysozyme, $1 \mathrm{X}$ in-house protease inhibitor cocktail and subjected into 3 cycles of freeze-thaw in liquid nitrogen and cold water $\left(4-10^{\circ} \mathrm{C}\right)$. The cell suspension was sonicated by 3 bursts of $30 \mathrm{~s}$ each at $60 \%$ maximal power and then centrifuged at $10,000 \mathrm{x} \mathrm{g}$ for $20 \mathrm{~min}$. A fixed amount of IBs were solubilized at a given temperature or inducer concentration. The soluble (supernatant) fraction was analyzed by SDS-PAGE, and the amount of solubilization at different conditions was measured by SDSPAGE.

\section{Optimal Conditions for the Expression and Purification of the Highest Level of ORF2}

The cells were grown in TY2X medium at $37^{\circ} \mathrm{C}$ till reached the OD600 of 0.5 , and IPTG was added to a final concentration of at least $0.5 \mathrm{mM}$ at $28^{\circ} \mathrm{C}$ for $5 \mathrm{~h}$. The cells were harvested at $8,000 \times \mathrm{g}$ for $5 \mathrm{~min}$ at $4^{\circ} \mathrm{C}$. The cells pellet was resuspended in $15 \mathrm{ml}$ of ice-cold Buffer A $(300 \mathrm{mM} \mathrm{NaCl}$ and $50 \mathrm{mM} \mathrm{NaH} 2 \mathrm{PO} 4)$ and sonicated for $5 \mathrm{sec}$ and incubated on ice for $30 \mathrm{~min}$. The lysate was centrifuged at $10,000 \mathrm{x}$ g for $15 \mathrm{~min}$ at $4^{\circ} \mathrm{C}$. The cell pellet was resuspended in $15 \mathrm{ml}$ of Buffer A containing Triton-x100 and 1\% Tween-20, then sonicated for 5 sec and incubated on ice for $30 \mathrm{~min}$. After harvesting the lysate at $10,000 \mathrm{x}$ g for $15 \mathrm{~min}$ at $4^{\circ} \mathrm{C}$, the cell pellet was resuspended in $15 \mathrm{ml}$ of Buffer A containing $1 \mathrm{mM}$ DTT and repeated with $50 \mathrm{mM} \mathrm{MgCl} 2$ containing DNAse, RNAse $1 \mathrm{UI} / \mathrm{ml}$ then $1 \mathrm{M}$ urea that will not lyse the IBs, but will solubilize cell debris. The proteins were sonicated for $5 \mathrm{sec}$ and incubated on ice for $30 \mathrm{~min}$. These steps were repeated with $2 \mathrm{M}$ urea and 3 times $30 \mathrm{sec}$ sonication. This way, the recombinant proteins in the IBs were urea-solubilized and rotated at $4^{\circ} \mathrm{C}$ for $30 \mathrm{~min}$. The supernatant containing ORF2 protein was collected and loaded onto a Ni-NTA spin column, and the flow-through was collected. The column was washed with $600 \mu \mathrm{l}$ Buffer A and 1 M Urea, and the wash was repeated with Buffer A without Urea. The third wash was performed using Buffer A with 10 $\mathrm{mM}$ Imidazole. Finally, the protein was eluted with Buffer A with $200 \mathrm{mM}$ imidazole. The samples were also evaluated by SDS-PAGE.

\section{Structure Prediction}

The homology modeling of the desired sequence was conducted on 2ztn-A, 2zzq, 2zzq-A, and 3ggq-A PDB ID Using 
the I- TASSER Protein Structure and Function Predictions webserver $[17,18]$.

\section{Circular Dichroism (CD) Evaluations}

The far-UV CD evaluations were measured using J-810 spectropolarimeter (JASCO, Canada) with a $1 \mathrm{~mm}$ path length at $25^{\circ} \mathrm{C}$. The protein concentration was measured $0.5 \mathrm{mg} / \mathrm{ml}$ in the presence of $50 \mathrm{mM}$ sodium phosphate buffer $(\mathrm{pH} 8)$. The $\mathrm{CD}$ spectra were deconvoluted based on the spectra ranging from 190 to $350 \mathrm{~nm}$ using the CDNN CD Spectra Deconvolution Software (version 2.1, Japan).

\section{ELISA}

ELISA wells (SPL, South Korea) were coated overnight at $4^{\circ} \mathrm{C}$ with $100 \mu \mathrm{l}$ of $3 \mu \mathrm{g} / \mathrm{ml}$ solution of recombinant ORF2 in PBS ( $\mathrm{pH} \mathrm{8)}$ and washed with washing buffer (10 mM PBS (pH7), $0.05 \%$ Tween-20) and blocked for $2 \mathrm{~h}$ at room temperature with blocking buffer (3\% BSA/0.05\% Tween-20) in TBS, (TBS: $10 \mathrm{mM}$ Tris-base, $150 \mathrm{mM} \mathrm{NaCl}$, (pH 7.2)). Sera obtained from 15 patients (collected at Firoozgar Hospital, Tehran, Iran) were diluted serially from 1: 10 to 1:80 in PBS and $100 \mu \mathrm{l}$ of each dilution was added into the wells duplicately. Then, the plate was incubated at $37^{\circ} \mathrm{C}$ for $1 \mathrm{~h}$. The wells were washed with $1 \mathrm{X}$ PBS $/ 0.05 \%$ Tween-20 and then HRP-conjugated secondary antibody (anti-Human polyvalent immunoglobulins (G, A, M) peroxidase, (Sigma-Aldrich, Germany), diluted 1: 10,000 in blocking buffer was added. After $1 \mathrm{~h}$ incubation at $37^{\circ} \mathrm{C}$ and washing the membrane, the bound HRP was visualized by adding $100 \mu \mathrm{l}$ of TMB (DIAPRO, Italy). The reaction was stopped after $15 \mathrm{mins}$ by the addition of $100 \mu \mathrm{l} 0.3 \mathrm{M} \mathrm{H} 2 \mathrm{SO} 4$. The optical densities were measured at $450 \mathrm{~nm}$. The cut-off was measured as OD450 =3, and a positive serum sample with the absorbance higher than 3 was considered as positive control, and a healthy serum was used as negative.

\section{RESULTS}

\section{SDS-PAGE and Western Blot Analyses}

SDS-PAGE revealed an over-expressed $\sim 27 \mathrm{kDa}$ band in the protein extracts of the cells transfected with pET26b-ORF2 and induced with IPTG (Fig. 1). A similar-size band was detected by Western Blot analysis (Fig 2).

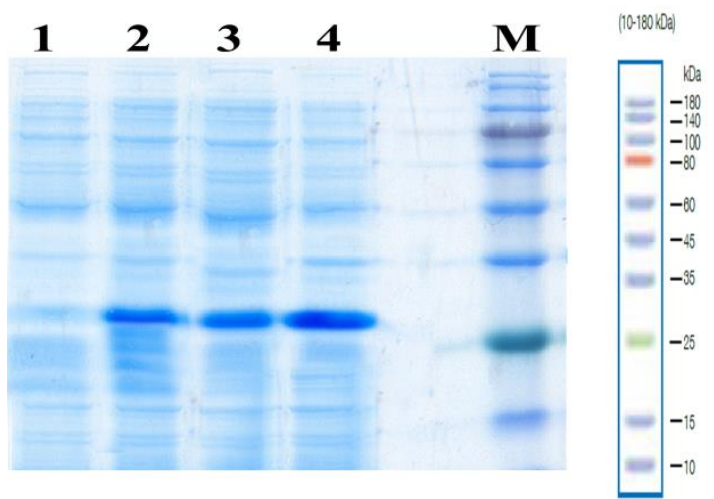

Fig. 1. SDS-PAGE. 1: Uninduced, 2: 2 hours after induced, 3: 3 h after induced, 4: $5 \mathrm{~h}$ after induced, M: Protein Marker (Blue Plus IV Protein Marker (10- $180 \mathrm{kDa}$ )-Transgen Biotech). No significant difference was detected between the fractions at different induction times.

Solubility Assays
Consistent with previous studies, we obtained considerable amounts of IBs upon high-level expression of ORF2 in E. coli (Fig. 3). We observed ORF2 in the insoluble fraction, and there was a low amount of soluble ORF2. Without modifying the protein extraction procedure, the quantity of soluble ORF2 was significantly increased by lowering the induction temperatures $\left(16-20^{\circ} \mathrm{C}\right.$; Fig 3). These conditions were applied to subsequent experiments.

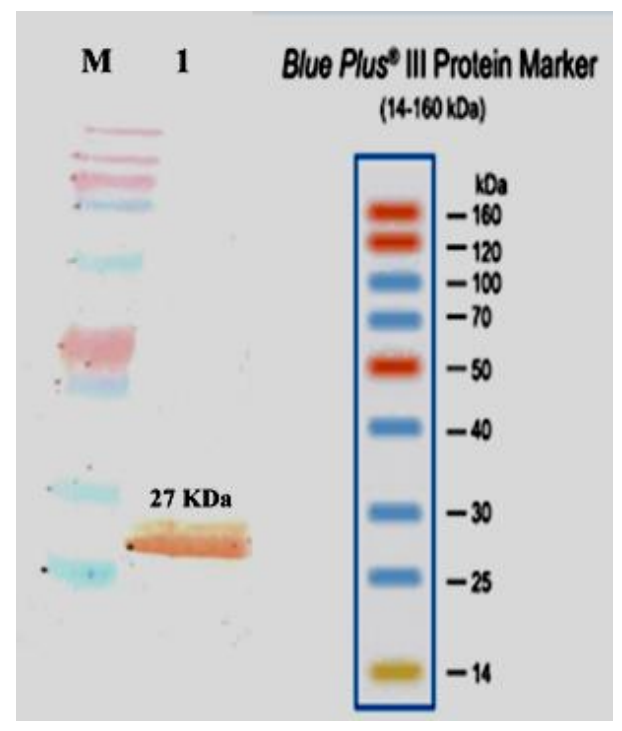

Fig. 2. Western Blot. M: Protein Marker (Blue Plus IV Protein Marker (14- $160 \mathrm{KDa}$ )-Transgen Biotech, 1: expressed ORF2.

We also demonstrated that the formation of IBs could be decreased using a low concentration of IPTG (up to $0.1 \mathrm{mM}$ ). Furthermore, the effects of Triton X-100 and Tween-20 were assessed. The results showed that the application of Triton X100 and Tween-20 did not increase the solubility of ORF2. To assess the protein solubility, different buffer volumes were also applied to determine the protein concentration as another factor in IB formation. Reducing agents often prevent IB formation by inhibiting the formation of non-native intermolecular disulfide bonds; however, no significant effect of $\beta$-mercaptoethanol on IB formation was observed (data not shown).

\section{$\begin{array}{llll}P & \text { S1 } & \text { S2 } & \text { S3 }\end{array}$}

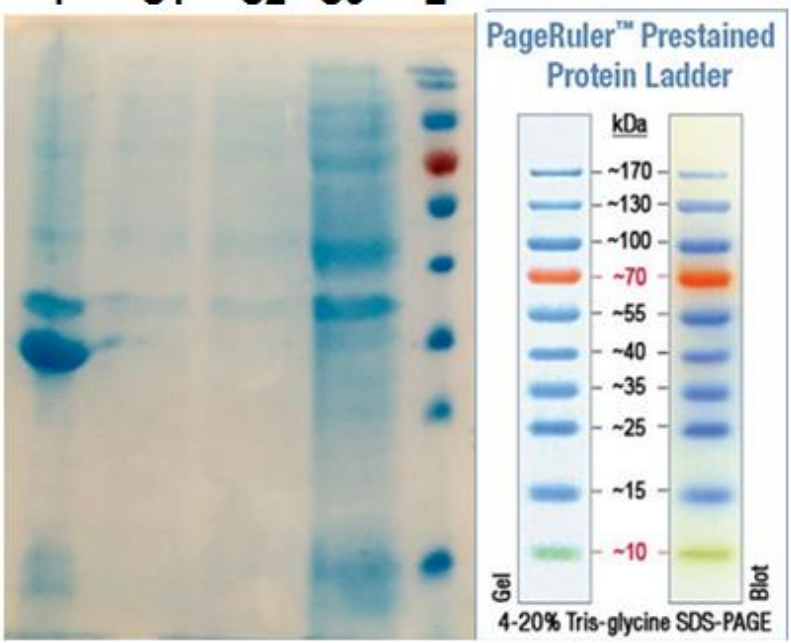

Fig. 3. Western Blot. P: pellet fraction after 3 rounds of sonication and centrifugation. S1: soluble fraction after first sonication. S2: soluble fraction after twice sonication, S3: soluble fraction after third sonication. L: Protein Marker (PageRuler ${ }^{\mathrm{TM}}$ Prestained Protein Ladder $(10-170 \mathrm{kDa})$ )-Fermentas. A significant amount of protein of interest was not achieved by first, second and third rounds of sonication 
Moreover, ORF2 was not soluble in Buffer A containing Triton 100x, Tween-20 and DNAse/RNAse. Weak solubility was observed in Buffer A containing 1M urea (data not shown). Hence, the IB pellets were resuspended in Buffer A, containing $2 \mathrm{M}$ urea $(\mathrm{pH} 8)$, and the supernatant of ORF2 protein was collected as the optimal conditions for the expression and purification.

\section{Secondary structure by homology modeling}

To predict secondary structure (Fig. 4), we used ITASSER (Zhang lab) webserver. The I-TASSER showed the following results: Helix (11.5\%), Strand (32.5\%) and Coil $(56 \%)$.

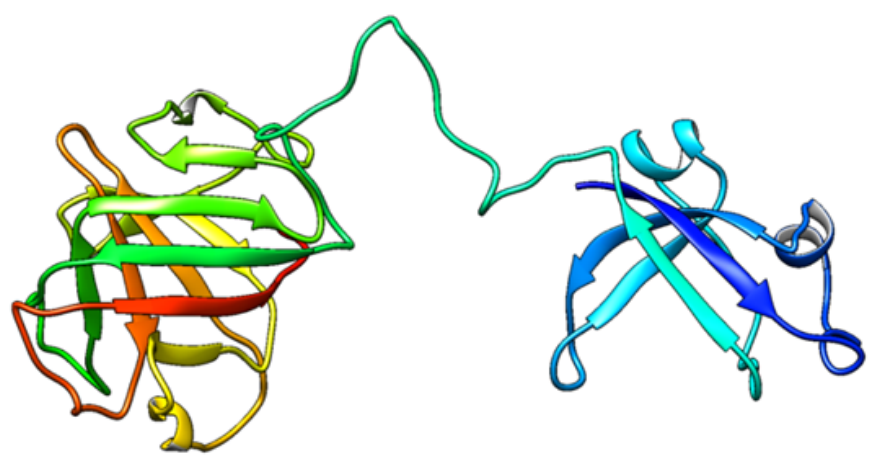

Fig. 4. Predicted special structure of HEV-ORF2 by I-TASSER

\section{Circular Dichroism (CD) Spectroscopy}

Secondary structure was also determined using CD. The far-UV CD spectra of ORF2 were measured at $\mathrm{pH} 7.4$ and $25^{\circ} \mathrm{C}$. The content of the secondary structure was determined by spectral analysis using CDNN software. Based on the CD results, the ORF2 had 18\% helix content, $39 \%$ extended strand, $13.7 \%$ turn and $29.3 \%$ random coils (Fig. 5), which confirmed the prediction by the homology modeling, especially with respect to the percentages of the helices and sheets.

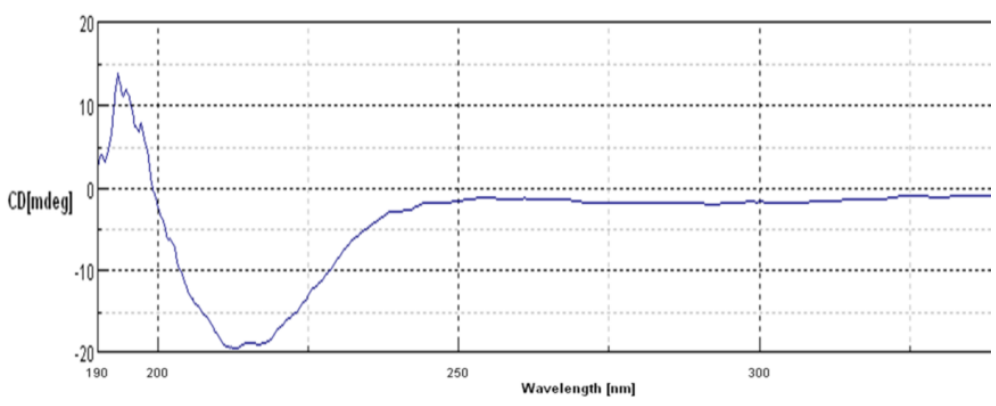

Fig. 5. CD spectrum of the ORF2 acquired on Jasco- 810 spectropolarimeter.

Altogether, the above data confirms that the recombinant ORF2 has retained its conformational stability because the percentages of its $\alpha$-helix and $\beta$-sheet secondary structure has not changed drastically after the purification and has not been converted to random coils.

\section{ELISA}

As shown in Fig. 6, the solubilized ORF2 was functional as an antigen and bound to the anti-ORF2 antibody, presented in sera from all 15 patients.

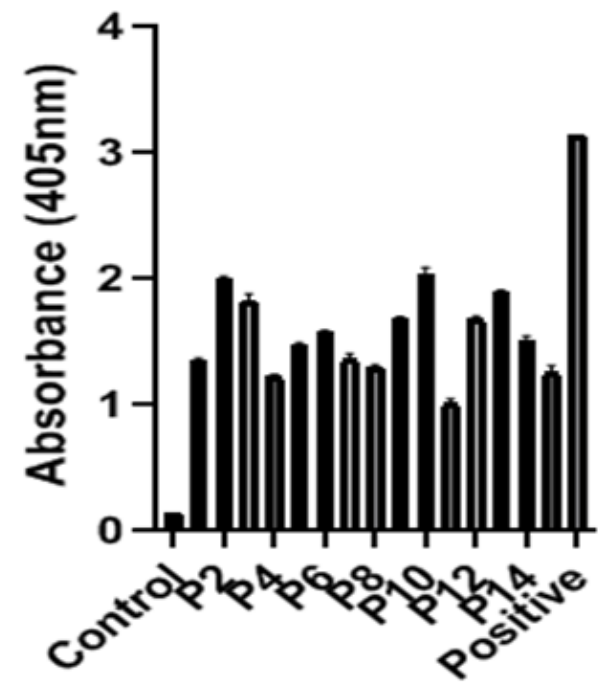

Samles number

Fig. 6. ELISA results of patients' serums on the coatedORF2 protein. The data shows the absorbance of P1 to P15 (Patient 1 to Patient 2) serum between the range of the absorbance of negative control and the positive samples.

\section{DISCUSSION}

The formation of IBs and the nature of intermediates involved in the aggregation are defined by the biochemical features of the recombinant proteins and the conditions under which the expression and the purification steps are performed [19]. Non-specific interactions, as another factor, may be involved in protein aggregations. Some buffer additives have been efficient in lowering such interactions for increasing protein solubility [20]. The protein expression can be modified by manipulating the induction temperatures, media compositions, and inducer concentrations to improve the yield of soluble proteins [14]. Truncated ORF2 (26 kDa and $54 \mathrm{kDa})$ have been expressed in a research published in 2018 in which E. coli BL21 competent cells containing vectors encoding truncated orf 2 were induced by $0.2 \mathrm{mM}$ IPTG at $37{ }^{\circ} \mathrm{C}$ for 2.5 $\mathrm{h}$, and the assessment of the expressed protein showed that ORF2 was overexpressed. However, approximately 55\% and $80 \%$ of $26 \mathrm{kDa}$ and $54 \mathrm{kDa}$ ORF2, respectively, were in soluble form and the rest of those were insoluble[21].

To recover target recombinant proteins from the IBs, classical methods are focused on using high concentrations of denaturing agents, including guanidinium chloride, urea, and detergents, which cause the unfolding of the entire solubilized protein molecules and consequently increase the aggregation chance while refolding lowers the recovery yield of bioactive proteins. Hence, optimizing solubilization methods can improve the biological activity of the proteins of interest, after their refolding. In the present study, chemicals with low concentrations were used for the solubilization of recombinant ORF2 protein to prepare a low denaturing environment. We achieved new combinations of chemicals by combining low concentrations of urea and detergents, which proved to be effective methods to gain the nature-folded recombinant proteins from IBs produced in E. coli.

ORF2 is a monomeric protein with a molecular weight of approximately $27 \mathrm{kDa}$. The SDS-PAGE results indicated that the presence of one major protein around the $27 \mathrm{kDa}$ range. We 
have presented here some basic properties of the native protein as a start towards extraction and purification of active protein. The previous studies demonstrated that ORF2 formed IBs in bacteria, and it was dissolved in $4 \mathrm{M}$ urea [22]. We conducted $\mathrm{CD}$ on the purified ORF2 protein to analyze the conformational stability and the elements of secondary structure. The overall similariy between between I-TASSER and $C D$ results indicated the percentages of helices and sheets after the purification of expressed HEV-ORF2 was retained. Furthermore, it showed that the protein was stable in $2 \mathrm{M}$ urea. Because of the destructive nature of the urea on the native-like secondary structure of IBs, low concentration of urea can preserve the biological activity of proteins while solubilizing them. Refolding of the protein of interest from a misfolded form would be easier than refolding it from an entirely unfolded state. It has been shown that solubilization of IB proteins under the condition of high concentrations of chemicals can cause higher hydrophobicity and increased chance of aggregation while refolding it would increase the yield of recovery for a bioactive protein [23]

According to the literature, IBs may contain some amounts of catalytically active recombinant protein. However, in most researches with IBs due to overexpression of the gene of interest, the activities of the proteins are rarely assessed. For proteins carrying multiple cysteine residues, 2ME or DTT are added to reduce the incorrect disulfide bonds that exist in the host proteins and the recombinant proteins in IB. It is commonly thought that the expression in low temperature can lead to the formation of active IBs; however, the supernatant may contain all of the soluble cytosolic proteins. Interestingly, the formation of active IB at high temperatures has also been reported [11]. Our ELISA results showed that the expressed and the solubilized ORF2 could both react to a specific anti-HEV antibody in sera of HEV-infected patients.

In conclusion, the high concentration of urea and other denaturants cause aggregation of the recombinant proteins and their misfolding. Therefore, during recovering a protein, it would be important to decrease the concentration of denaturants, to achieve an accurate protein refolding. Another way to reach a higher concentration of ORF2 in the soluble fraction is the induction of protein expression at low temperatures. Here, the induction temperature of $16^{\circ} \mathrm{C}$ led to slow expression of ORF2 and consequently, low IBs quantity without significant changes in the secondary structure of the protein of interest. Using a low concentration of urea in composition with a low concentration of detergents could effectively recover the expressed recombinant protein from the IBs. On the other hand, the use of non-ionic detergents such as Triton X-100 and Tween-20 did not increase the solubility of recombinant ORF2 expressed at low temperatures. Protein solubility using various buffers were also assessed to determine protein concentration as another major agent in protein aggregation. Reducing agents often prevent the formation of IBs by inhibiting the formation of unwanted intermolecular disulfide bonds; however, $\beta$-mercaptoethanol had no significant effect on the solubilization. Upon further evaluations, ORF2 expression in low temperature, which favors the formation of active IBs can be considered as a candidate for $\mathrm{s}$ recombinant vaccine against $\mathrm{HEV}$ infection or as a diagnostic protein for the detection of anti-ORF2 antibody in suspected persons using sandwich-ELISA.

\section{ACKNOWLEDGEMENT}

The authors would like to acknowledge the Department of Hepatitis and AIDS of Pasteur Institute of Iran. This work was financially supported by Pasteur Institute of Iran (Grant \#1055).

\section{CONFLICT OF INTEREST}

The authors declare that they have no conflict of interest.

\section{REFERENCES}

1. Kamili S. Toward the development of a hepatitis E vaccine. Virus Res. 2011;161(1):93-100. doi:10.1016/j.virusres.2011.05.008.

2. Accessed

WHO.http://www.who.int/mediacentre/factsheets/fs280/en/ Accessed on June 20, 2017.

3. Ahmad I, Holla RP, Jameel S. Molecular virology of hepatitis E virus. Virus Res. 2011;161(1):47-58. doi:10.1016/j.virusres.2011.02.011.

4. Behloul N, Wei W, Baha S, Liu Z, Wen J, Meng J. Effects of mRNA secondary structure on the expression of HEV ORF2 proteins in Escherichia coli. Microb Cell Fact. 2017;16(1):200. doi:10.1186/s12934-017-0812-8.

5. Wen J, Lu W, Liu Z, Meng J. Establishment of a Competitive Binding Assay Identifying the Different Characteristics of Neutralizing Epitopes of Hepatitis E Virus. Intervirology. 2017;60(5):190-5.

6. Aggarwal R, Jameel S. Hepatitis E vaccine. Hepatol Int. 2008;2(3):308-15. doi:10.1007/s12072-008-9071-4.

7. Zhang X, Wei M, Pan H, Lin Z, Wang K, Weng Z et al. Robust manufacturing and comprehensive characterization of recombinant hepatitis $\mathrm{E}$ virus-like particles in Hecolin $((\mathrm{R}))$. Vaccine. 2014;32(32):4039-50. doi:10.1016/j.vaccine.2014.05.064.

8. Sadeghi S, Shahanaghi M, Aghasadeghi M, Motevalli F, Amiran M, Mohammadi Pargoo S et al. Cloning and expression of hepatitis E virus ORF2 as an immunogen protein in baculovirus expression system. Vaccine Research. 2018;5(1):23-6.

9. SADEGHI S, AGHASADEGHI M, AMIRAN M, BAHRAMALI G, Rahimi P, OWLIA P et al. Cloning and expression of hepatitis E virus ORF2 as a vaccine candidate. 2017.

10. Dubendorff JW, Studier FW. Controlling basal expression in an inducible $\mathrm{T} 7$ expression system by blocking the target T7 promoter with lac repressor. J Mol Biol. 1991;219(1):45-59.

11. Cabrita LD, Bottomley SP. Protein expression and refolding--a practical guide to getting the most out of inclusion bodies. Biotechnol Annu Rev. 2004;10:31-50. doi:10.1016/S1387-2656(04)10002-1.

12. Khan RH, Rao KB, Eshwari AN, Totey SM, Panda AK. Solubilization of recombinant ovine growth hormone with retention of native-like secondary structure and its refolding from the inclusion bodies of Escherichia coli. Biotechnol Prog. 1998;14(5):722-8. doi:10.1021/bp980071q.

13. Peternel S, Komel R. Isolation of biologically active nanomaterial (inclusion bodies) from bacterial cells. Microb 
Cell Fact. 2010;9:66. doi:10.1186/1475-2859-9-66.

14. Costa S, Almeida A, Castro A, Domingues L. Fusion tags for protein solubility, purification and immunogenicity in Escherichia coli: the novel Fh8 system. Front Microbiol. 2014;5:63. doi:10.3389/fmicb.2014.00063.

15. Zou J-p, Xu J, Liu L, Li S, Wu C, Du G. Solubilization and purification of Escherichia coli expressed GST-fusion human vascular endothelial growth factors with $\mathrm{N}$ Lauroylsarcosine. African Journal of Biotechnology. 2009;8(10).

16. Mazalovska M, Varadinov N, Koynarski T, Minkov I, Teoharov P, Lomonossoff GP et al. Detection of Serum Antibodies to Hepatitis E Virus Based on HEV Genotype 3 ORF2 Capsid Protein Expressed in Nicotiana benthamiana. Annals of laboratory medicine. 2017;37(4):313-9.

17. Roy A, Kucukural A, Zhang Y. I-TASSER: a unified platform for automated protein structure and function prediction. Nature protocols. 2010;5(4):725.

18. Zhang Y. I-TASSER server for protein 3D structure prediction. BMC bioinformatics. 2008;9(1):40.

19. Castellanos-Mendoza A, Castro-Acosta RM, Olvera A, Zavala G, Mendoza-Vera M, Garcia-Hernandez E et al. Influence of $\mathrm{pH}$ control in the formation of inclusion bodies during production of recombinant sphingomyelinase-D in Escherichia coli. Microb Cell Fact. 2014;13:137. doi:10.1186/s12934-014-0137-9.

20. Yamaguchi H, Miyazaki M. Refolding techniques for recovering biologically active recombinant proteins from inclusion bodies. Biomolecules. 2014;4(1):235-51. doi:10.3390/biom4010235.

21. Rani D, Saxena R, Nayak B, Srivastava S. Cloning and expression of truncated ORF2 as a vaccine candidate against hepatitis E virus. 3 Biotech. 2018;8(10):414.

22. Farshadpour F, Makvandi M, Taherkhani R. Design, Construction and Cloning of Truncated ORF2 and tPAspPADRE-Truncated ORF2 Gene Cassette From Hepatitis E Virus in the pVAX1 Expression Vector. Jundishapur $\mathbf{J}$ Microbiol. 2015;8(12):e26035. doi:10.5812/jjm.26035.

23. Mohammadian A, Kaghazian H, Kavianpour A, Jalalirad R. Solubilization of inclusion body proteins using low and very low concentrations of chemicals: implications of novel combined chemical treatment designs in enhancement of post-solubilization target protein purity and biological activity. J Chem Technol Biot. 2018;93(6):1579-87. doi:10.1002/jctb.5525. 